Studies by the U.S. Geological Survey in Alaska, Volume 15

\title{
Hydrogeochemical Exploration-A Reconnaissance Study on Northeastern Seward Peninsula, Alaska
}

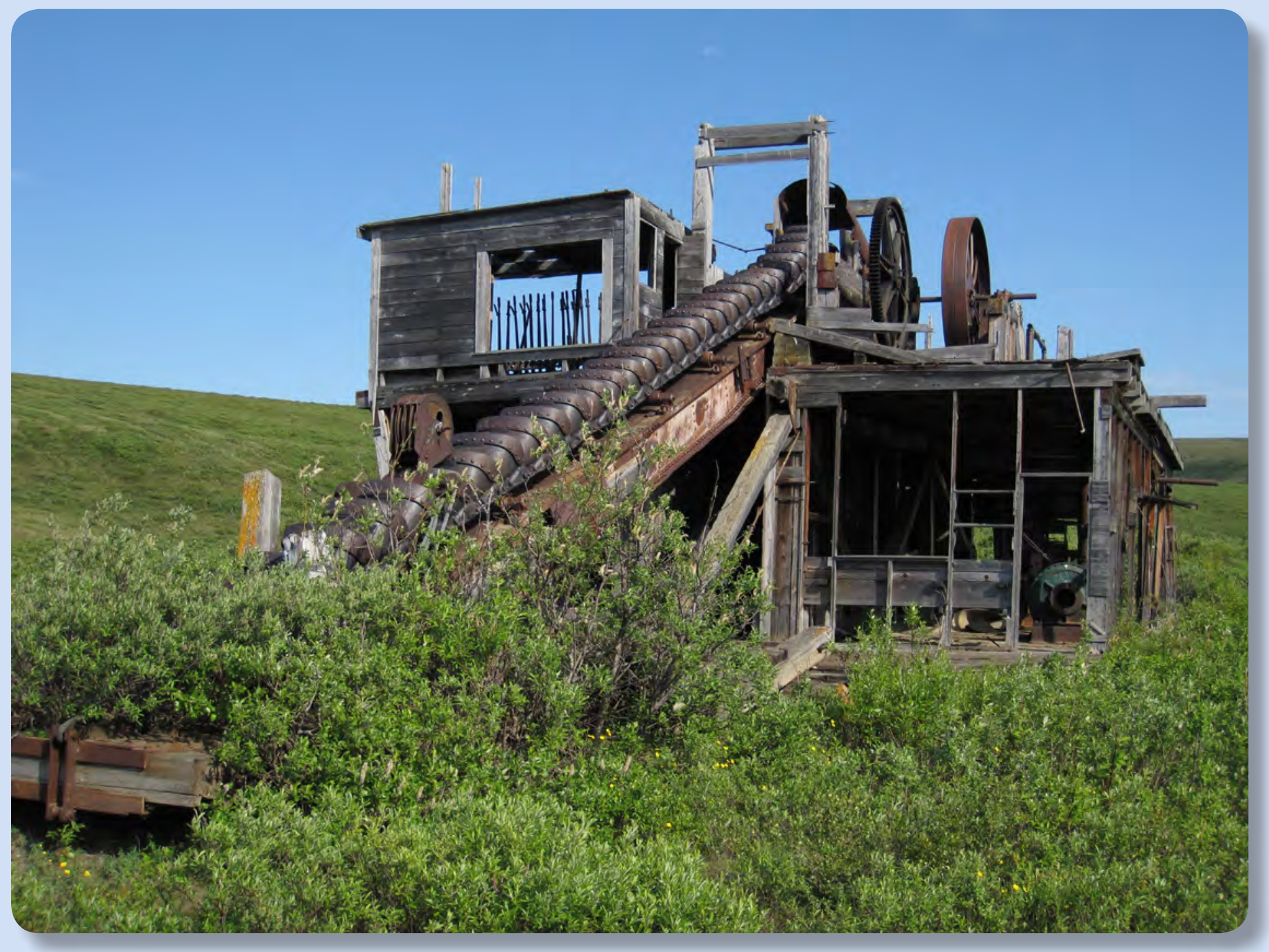

Professional Paper 1814-A 


\section{FRONT COVER}

Photograph of abandoned dredge near historic Utica gold camp, Seward Peninsula, Alaska (U.S. Geological Survey photograph by Garth E. Graham). 
Studies by the U.S. Geological Survey in Alaska, Volume 15

\section{Hydrogeochemical Exploration-A Reconnaissance Study on Northeastern Seward Peninsula, Alaska}

By Garth E. Graham, Ryan D. Taylor, and Steve Buckley

Professional Paper 1814-A 


\title{
U.S. Department of the Interior SALLY JEWELL, Secretary
}

\section{U.S. Geological Survey \\ Suzette M. Kimball, Acting Director}

\author{
U.S. Geological Survey, Reston, Virginia: 2015
}

For more information on the USGS - the Federal source for science about the Earth, its natural and living resources, natural hazards, and the environment—visit http://www.usgs.gov or call 1-888-ASK-USGS.

For an overview of USGS information products, including maps, imagery, and publications, visit http://www.usgs.gov/pubprod/.

Any use of trade, firm, or product names is for descriptive purposes only and does not imply endorsement by the U.S. Government.

Although this information product, for the most part, is in the public domain, it also may contain copyrighted materials as noted in the text. Permission to reproduce copyrighted items must be secured from the copyright owner.

Suggested citation:

Graham, G.E., Taylor, R.D., and Buckley, S., 2015, Hydrogeochemical exploration-A reconnaissance study on northeastern Seward Peninsula, Alaska, in Dumoulin, J.A., ed., Studies by the U.S. Geological Survey in Alaska, vol. 15: U.S. Geological Survey Professional Paper 1814-A, 16 p., http://dx.doi.org/10.3133/pp1814A.

ISSN 2330-7102 (online) 


\section{Acknowledgments}

This study was conducted with logistical support from NANA Regional Corporation (NANA). We thank NANA, and particularly Lance Miller, for access to the study area and

logistical and funding support during fieldwork. Steve Smith, David Fey, Karen Kelley, and Julie Dumoulin provided useful comments that helped improve an earlier version of this manuscript. Peter Stauffer provided editorial assistance. 


\section{Contents}

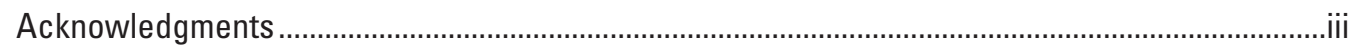

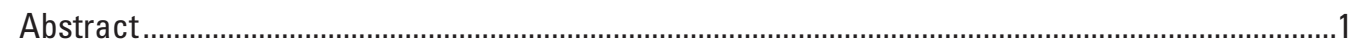

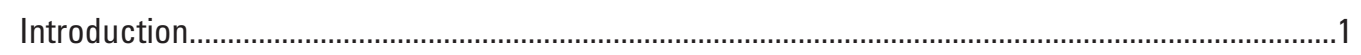

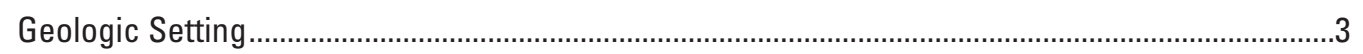

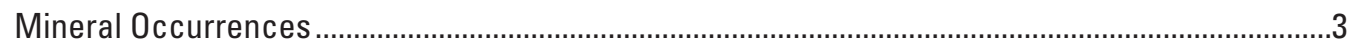

Conceptual Model of Possible Bedrock Gold Sources .........................................................

Methods

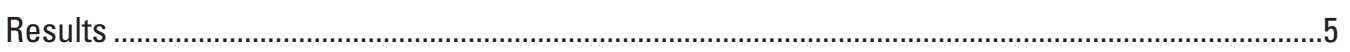

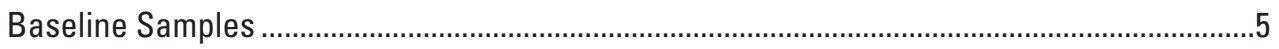

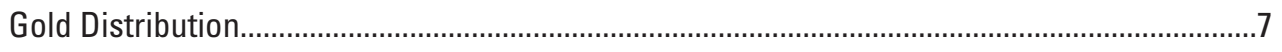

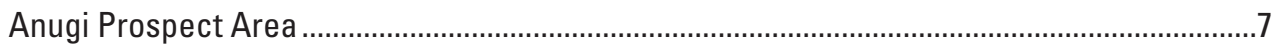

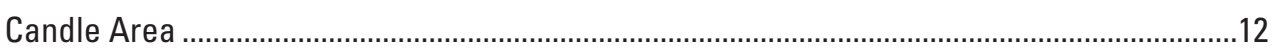

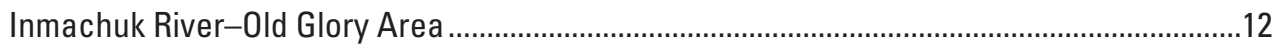

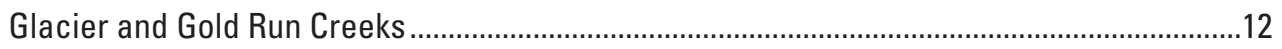

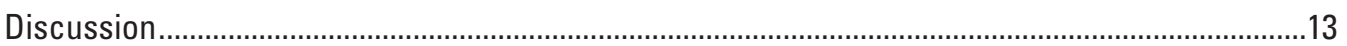

Comparison of Hydrogeochemical Data with Historical Stream Sediment Data ...................13

Effectiveness of Pb-Zn-Ag Deposit Detection Anugi Region .................................................13

Interpretations of Inmachuk River-Old Glory Creek Data ...................................................13

Interpretations of Candle Area and Monument Mountain Area Data .....................................14

Possible Geologic Controls on Observed Hydrochemistry ...................................................14

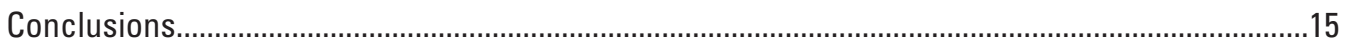

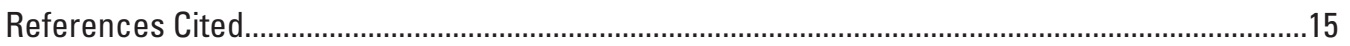

\section{Figures}

1. Generalized location map of the study area in part of the Fairhaven mining district in the northeastern Bendeleben quadrangle, Seward Peninsula, Alaska .

2. Piper triangular diagram (Piper, 1944) showing major-ion composition (cations calcium, magnesium, sodium + potassium; anions chloride, sulfate, carbonate + bicarbonate) for water samples from study area in northeastern Seward Peninsula, Alaska...

3. Maps showing locations of anomalous metal concentrations in water samples from study area, northeastern Seward Peninsula, Alaska.....

\section{Table}

1. Summary statistics for select chemical constituents and parameters in filtered water samples from streams and seeps in the northeastern Seward Peninsula, Alaska.... 


\section{Conversion Factors}

International System of Units to Inch/Pound

\begin{tabular}{lll}
\hline \multicolumn{1}{c}{ Multiply } & \multicolumn{1}{c}{ By } & \multicolumn{1}{c}{ To obtain } \\
\hline meter $(\mathrm{m})$ & \multicolumn{2}{c}{ Length } \\
kilometer $(\mathrm{km})$ & 3.281 & foot $(\mathrm{ft})$ \\
square centimeter $\left(\mathrm{cm}^{2}\right)$ & 0.6214 & mile $(\mathrm{mi})$ \\
& 0.001076 & square foot $\left(\mathrm{ft}^{2}\right)$ \\
\hline \multicolumn{2}{c}{ Volume } & \\
\hline milliliter $(\mathrm{mL})$ & 0.033814 & ounce, fluid (fl. oz) \\
\hline nanogram per milliliter $(\mathrm{ng} / \mathrm{mL})$ & 0.001 & Other \\
\hline
\end{tabular}

Temperature in degrees Fahrenheit $\left({ }^{\circ} \mathrm{F}\right)$ may be converted to degrees Celsius $\left({ }^{\circ} \mathrm{C}\right)$ as follows:

${ }^{\circ} \mathrm{C}=\left({ }^{\circ} \mathrm{F}-32\right) / 1.8$

\section{Chemical Symbols Used}

\begin{tabular}{ll}
\hline $\mathrm{Ag}$ & Silver \\
$\mathrm{Al}$ & Aluminum \\
$\mathrm{Ar}$ & Argon \\
$\mathrm{As}$ & Arsenic \\
$\mathrm{Au}$ & Gold \\
$\mathrm{Ca}$ & Calcium \\
$\mathrm{Cd}$ & Cadmium \\
$\mathrm{Cu}$ & Copper \\
$\mathrm{Fe}$ & Iron \\
$\mathrm{K}$ & Potassium \\
$\mathrm{Li}$ & Lithium \\
$\mathrm{Mo}$ & Molybdenum \\
$\mathrm{Na}$ & Sodium \\
$\mathrm{Pb}$ & Lead \\
$\mathrm{Rb}$ & Rubidium \\
$\mathrm{Sb}$ & Antimony \\
$\mathrm{Se}$ & Selenium \\
$\mathrm{Sr}$ & Strontium \\
$\mathrm{Tl}$ & Thallium \\
$\mathrm{U}$ & Uranium \\
$\mathrm{W}$ & Tungsten \\
$\mathrm{Zn}$ & Zinc \\
\hline
\end{tabular}





\title{
Hydrogeochemical Exploration-A Reconnaissance Study on Northeastern Seward Peninsula, Alaska
}

\author{
By Garth E. Graham', Ryan D. Taylor', and Steve Buckley²
}

\section{Abstract}

A reconnaissance hydrogeochemical study employing high-resolution/high-sensitivity inductively coupled plasma mass spectrometry analysis of stream and seep water samples $(n=171)$ was conducted in an area of limited bedrock exposure on the northeastern Seward Peninsula, Alaska. Sampling was focused in drainages around four main areas - at the Anugi $\mathrm{Pb}-\mathrm{Zn}$-Ag occurrence and in streams upstream of historically and currently mined placer gold deposits in the Candle Creek, Utica, and Monument Mountain areas. The objective of the study was to determine whether distribution of elevated metal concentrations in water samples could "see" through sediment cover and provide evidence of bedrock sources for base metals and gold. Some observations include (1) elevated Ag, As, Pb, and $\mathrm{Zn}$ concentrations relative to the study area as a whole in stream and seep samples from over and downstream of part of the Anugi $\mathrm{Pb}-\mathrm{Zn}$-Ag prospect; (2) abrupt downstream increases in $\mathrm{Tl}$ and $\mathrm{Sb} \pm \mathrm{Au}$ concentrations coincident with the upstream termination of productive placer deposits in the Inmachuk and Old Glory Creek drainages near Utica; (3) high K, Mo, Sb, and F throughout much of the Inmachuk River drainage near Utica; and (4) elevated As \pm base metals and Au at two sites along Patterson Creek near the town of Candle and three additional contiguous sites identified when an 85th percentile cut-off was employed. Molybdenum \pm gold concentrations ( $>90$ th percentile) were also measured in samples from three sites on Glacier Creek near Monument Mountain. The hydrogeochemistry in some areas is consistent with limited stream-sediment data from the region, including high $\mathrm{Pb}-\mathrm{Zn}-\mathrm{Ag}-\mathrm{As}$ concentrations associated with Anugi, as well as historical reports of arsenopyrite-bearing veins upstream of placer operations in Patterson Creek. Chemistry of samples in the Inmachuk River-Old Glory Creek area also suggest more laterally extensive stibnite- (and gold-?) bearing veining than is currently known in the Old Glory Creek drainage. Our results indicate that hydrogeochemistry can be a useful method of geochemical exploration and offer targets for follow-up rock, soil, and subsurface sampling to ascertain the presence of mineralized bedrock.

${ }^{1}$ U.S. Geological Survey.

${ }^{2}$ Sealaska Corporation.

\section{Introduction}

The northeastern part of the Seward Peninsula contains historically significant placer gold camps near Utica and Candle (fig. 1) that have produced the majority of the $\sim 500,000$ ounces of gold mined in the Fairhaven mining district (Hudson, 1999). Additionally, several base-metal occurrences have been identified in the region, including metamorphosed synsedimentary(?) or epigenetic deposits such as Anugi and Independence, as well as skarn deposits such as the Billiken Fe-Cu skarn (fig. 1; Hudson, 1999). Extensive vegetative cover with limited bedrock exposure and the presence of permafrost hamper our understanding of bedrock geology and potential additional mineral resources. Conventional reconnaissance stream sediment surveys (NANA Regional Corporation, unpublished data) have produced some limited success in identifying mineral prospects (for example, the Anugi prospect) but have been ineffective in identifying lode sources for placer gold.

Recent studies indicate that analysis of waters can be effective for identifying concealed mineral deposits (for example, Eppinger and others, 2012, 2013; Leybourne and Cameron, 2010, and references therein). Several studies have focused on groundwater collected from wells or drill holes (for example in Australia; Gray, 2001; Noble and Gray, 2010; Noble and others, 2010), whereas other studies have examined surface waters in addition to groundwater (for example, Eppinger and others, 2013; Kelley and Taylor, 1997; Kelley and others, 2010). Advances in analytical methods in the past 10-15 years that permit detection limits in the nanogram-per-liter (ng/L) range have enhanced the potential utility of hydrogeochemistry. For example, variations of ultralow metal concentrations in surface and groundwaters have been used to delineate mineralized rocks at the Pebble porphyry $\mathrm{Cu}-\mathrm{Au}-\mathrm{Mo}$ deposit in southwestern Alaska (Kelley and others, 2010; Eppinger and others, 2012, 2013).

Given the encouraging results of the Pebble study, we devised a hydrogeochemical study of surface and spring waters surrounding the partially exposed Anugi $\mathrm{Pb}-\mathrm{Zn}-\mathrm{Ag}$ deposit and areas upstream of mined placer gold deposits of the Candle, Utica, and Monument Mountain areas of the 1:250,000-scale Bendeleben quadrangle (fig. 1). The objective of the study was to determine if water chemistry could provide information useful in recognizing concealed base- and precious-metal mineralized rock. Our study tests the premise that stream waters are ultimately sourced from 


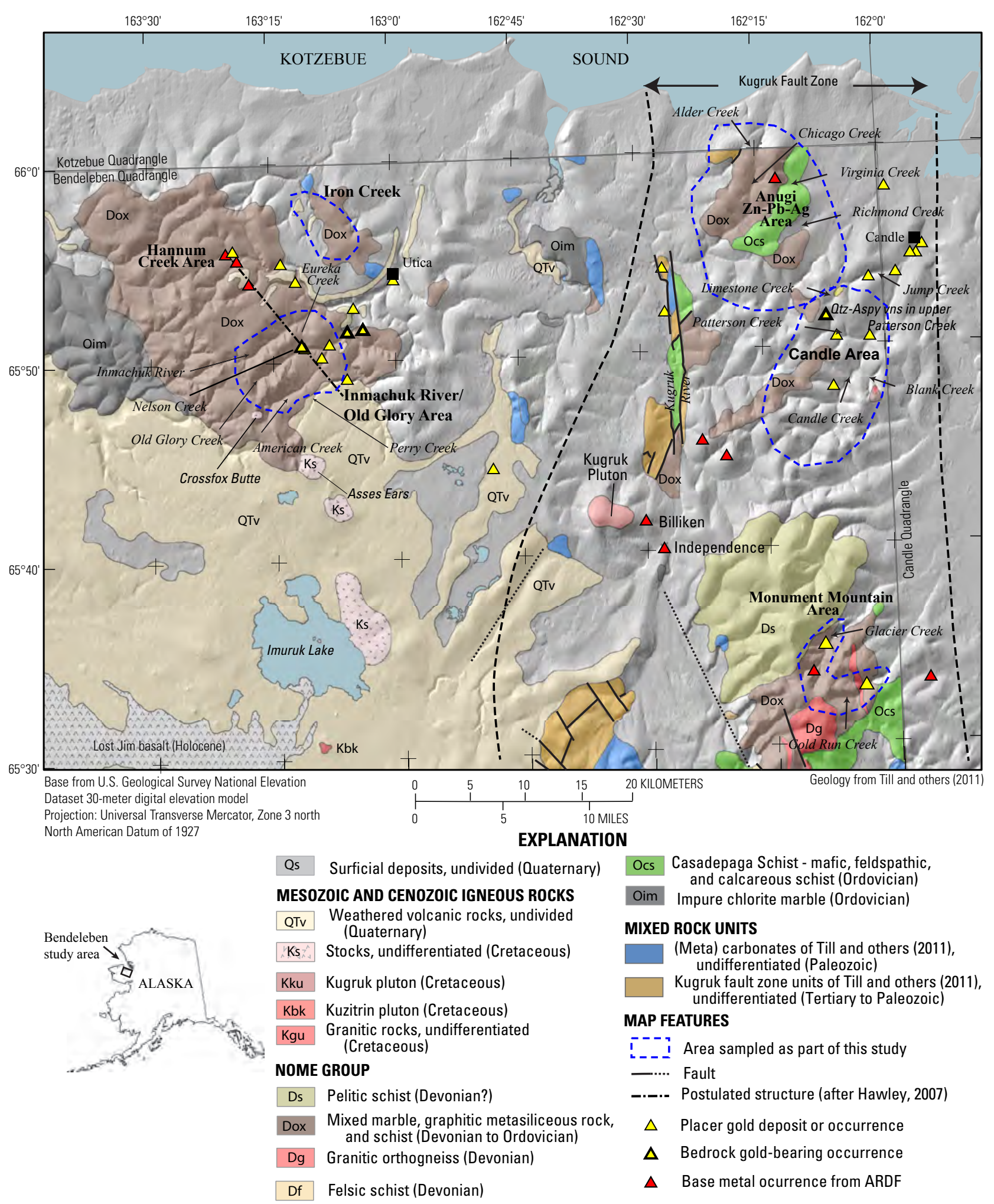

Figure 1. Generalized location map of the study area in part of the Fairhaven mining district in the northeastern Bendeleben quadrangle, Seward Peninsula, Alaska. General geologic units (mostly Nome Group) and features are from Till and others (2011). Mineral occurrences in the Bendeleben and Candle quadrangles are from Hudson (1999) and Williams (2000), respectively. White dashed lines mark areas where sampling was conducted. Potential structure linking Hannum Creek (not investigated in this study) and the Inmachuk River/Old Glory area has been added. ARDF, Alaska Resource Data File (http://ardf.wr.usgs.gov). 
initially dilute precipitation (snow, rain), but that at least a part of that water may have percolated into the subsurface and been chemically modified by interaction with soil and underlying bedrock before being discharged as seeps to enter the streams. Elevated concentrations of certain pathfinder elements (base metals, As, Sb), as well as $\mathrm{Au}$, could indicate interactions of some waters with mineralized rocks that were the ultimate sources of lode and placer deposits. Where mineralized bedrock has not been recently mechanically weathered, hydrogeochemistry of seeps might provide the only evidence of underlying mineralized rock.

\section{Geologic Setting}

Most of the Seward Peninsula is underlain by Neoproterozoic to lower Paleozoic metasedimentary continental margin rocks and metaigneous rocks of the Nome Complex (Till and others, 2011). In the northeastern portion of the Seward Peninsula, Till and others $(2011,2014)$ subdivide the Nome Complex on the basis of differences in composition. A unit made up of mixed pure and impure marble, graphitic metapelitic schist, calc-schist, and mafic schist (unit Dox) is structurally overlain locally by silvery green and greenish-brown mafic, feldspathic, and calcareous schist (unit Ocs; fig. 1; Till and others, 2011). Metabasites within both of these units display trace-element signatures interpreted to record deposition in a basin formed during early stages of continental rifting (Ayuso and Till, 2014). These rock units were intruded by Devonian granites (now orthogneiss) at Kiwalik Mountain (uranium-lead [U-Pb] zircon age of $391 \pm 3$ million years ago [mega-annum, Ma], Till and others, 2006), and all of these geologic units were subsequently metamorphosed during partial subduction along an active margin (Till and others, 2011, 2014) sometime between 170 and $100 \mathrm{Ma}$ (Armstrong and others, 1986).

Cretaceous (95-90 Ma) granitic to syenitic stocks intrude the Nome Complex in and near the study area. The Crossfox Butte and Asses Ears syenite stocks are exposed south of the Inmachuk River-Old Glory area (fig. 1) and form part of a northwest-trending belt of intrusive plugs. The Cretaceous Kugruk pluton intrudes carbonate-rich rocks within the Kugruk Fault Zone northwest of the Monument Mountain area (fig. 1).

Younger cover is locally extensive in the northeastern Seward Peninsula. Cenozoic basalt sheet flows cover large areas and are exposed along some river channels. Unconsolidated silty grey to tan deposits (loess?) are also abundant. The resultant terrain is one of rolling, tundra-covered hills with the most profound relief and exposure due to local high abundance of marble; schistose rocks are less extensively exposed.

The Kugruk Fault Zone (fig. 1) is a major north-south trending fault zone that roughly marks the eastern extent of Nome Group rocks and the approximate boundary with the Yukon-Koyukuk Basin to the east. The fault zone contains mostly greenschist-facies Nome Group, as well as slivers of mafic to ultramafic rocks of the Angayucham Terrane and Cretaceous (?) conglomerate and sandstone. The nature of this fault is poorly understood, but movement is thought to have been long-lived, occurring most recently during the Tertiary period (Till and others, 2011).

\section{Mineral Occurrences}

Placer gold mining has been historically important in the region, with production predominantly from the Utica and Candle placer camps, but with some recovery from the Kugruk River and in the Monument Mountain area (fig. 1; Hudson, 1999). Placer mining occurred in the main channel of the Inmachuk River near Utica and extended into many headwater streams to the south and west, including Hannum and Old Glory Creeks. Bedrock comprises lower Paleozoic metasedimentary rocks (unit Dox), although Cretaceous intrusions are exposed to the south (fig. 1). The placer gold is associated with quartz and cassiterite.

Mineralized bedrock occurrences around Hannum Creek and the Inmachuk River-Old Glory areas include base and precious metal types. Northwest-trending zones of gossan containing sphalerite, galena, and precious metals are most abundant near Hannum Creek (fig. 1). These poorly understood rocks are interpreted as carbonate-replacement $\mathrm{Pb}-\mathrm{Zn}-\mathrm{Ag}$ or metamorphosed stratiform occurrences hosted in siliceous schist (Hawley, 2007). To the southeast, in the Inmachuk River-Old Glory Creek area of the current study, auriferous quartz boudins (Herreid, 1966) and northwesttrending boulder trains of variably silicified and quartz-veined carbonate and schist containing stibnite, arsenopyrite, pyrite, and elevated gold concentrations occur within the Nelson Creek drainage basin (Herreid, 1966; Hawley, 2007).

The distribution of placer gold (and bedrock sources of metals) in the region may be structurally controlled (Hawley, 2007). Notably, the upstream extents of placer mining in the Inmachuk River-Old Glory Creek area (approximately at Nelson Creek) align along a northwest trend with the positions of replacement bodies near Hannum Creek (dashed line, fig. 1). A similar northwest-trending fault may have controlled the emplacement of Cretaceous syenite plutons $\sim 10$ kilometers $(\mathrm{km})$ to the south. The margin of one of these plutons, Crossfox Butte, contains anomalous metal concentrations, including tungsten and as much as 50 parts per million (ppm) molybdenum (Gamble 1988).

To the east, the Candle Creek placer area is within or adjacent to the poorly defined Kugruk Fault Zone. Historical placer mining extended from the lower reaches of Candle Creek near the town of Candle upstream, where mining is restricted to the main channel and adjacent benches or within western tributaries, including Jump and Patterson Creeks (Hudson, 1999). The bedrock in this area consists of lower Paleozoic metasedimentary rocks, with minor granitic rocks and intermediate to felsic dikes (fig. 1; Sandvick, 1956; Till and others, 1986; Hudson, 1999). Quartz-arsenopyrite veins, possible sources of gold, have been identified on Patterson Creek. The area is largely composed of rolling hills with poor 
Hydrogeochemical Exploration-A Reconnaissance Study on Northeastern Seward Peninsula, Alaska

exposure except in frost boils that have brought rock chips of the underlying strata to the surface.

To the south of Candle, smaller scale placer gold production has been reported on Glacier Creek and Gold Run Creek near Monument Mountain (fig. 1; Hudson, 1999). Monument Mountain is underlain by polydeformed Devonian pelitic schist. Local geology includes lower Paleozoic metasedimentary bedrock containing metamorphosed felsic dikes or sills possibly related to the Devonian Kiwalik Mountain gneiss (Till and others, 1986). Felsic metavolcanic rocks are present in parts of the Paleozoic sedimentary package and are known to locally host volcanogenic massive sulfide occurrences (Hudson, 1999). Tan-weathering metasediment (tuff?) was found in upper Glacier Creek in proximity to a $\mathrm{Pb}-\mathrm{Zn}-\mathrm{Ag}$ geochemical anomaly (Hudson, 1999). Scheelite, wolframite, and kyanite are present in placer concentrates from Gold Run Creek (Anderson, 1947).

The bedrock-hosted Anugi $\mathrm{Pb}-\mathrm{Zn}-\mathrm{Ag}$ prospect (a metamorphosed stratiform(?) or epigenetic fault-hosted system) occurs in rocks similar to those that host the Utica and Candle placer deposits and the $\mathrm{Pb}-\mathrm{Zn}-\mathrm{Ag}$ occurrences at and near Hannum Creek (fig. 1). Widespread anomalous concentrations of $\mathrm{Zn}$ and $\mathrm{Pb}$ in stream-sediment and soil samples (Williams, 2000) and drill intercepts of $>1$ weight percent zinc in multiple shallow drill holes (Hawley and Stevens, 2009) confirm that a large area of sphalerite-galenamineralized bedrock at or near the surface is being eroded into the east-draining streams. Additional shear-hosted $\mathrm{Pb}-\mathrm{Zn}-\mathrm{Ag}$ ores were mined historically from the Independence mine (fig. 1). The Billiken copper-bearing iron skarn (Newberry and others, 1997) occurs adjacent to the Kugruk pluton (potassium-argon [K-Ar] age of 94.9 $2.9 \mathrm{Ma}$; Till and others 1986) and represents a third potential type of base metal deposit associated with intrusions in the region.

\section{Conceptual Model of Possible Bedrock Gold Sources}

Large bedrock sources of gold are not currently known in the study area. However, available geologic data are permissive of proximal orogenic or intrusion-related gold sources for the placer gold deposits. In both Candle and Utica, placer gold is commonly associated with fragmental quartz. As also seen in the Nome mining district in the southwestern Seward Peninsula, bedrock lithologies associated with placer accumulations in the study area are locally carbonaceous low-grade metamorphic rocks. Arsenopyrite, a common pathfinder mineral for orogenic gold systems (Goldfarb and others, 2005) and a constituent associated with both the Rock Creek (Apodaca, 1992) and Big Hurrah lode deposits in the Nome district (Read and Meinert, 1986), has been identified in placers and veins in the Candle area (Hudson, 1999; Williams, 2000). The Utica placers contain cassiterite, a common heavy mineral found in placer gold deposits eroded from intrusion-related gold systems (Goldfarb and others, 2000). The presence of cassiterite that is spatially associated with
Cretaceous granitic intrusions could indicate potential for such systems upstream.

\section{Methods}

Stream and seep water samples were collected from 53 sites, including the Inmachuk River area, upper Chicago Creek, and several points on and near Iron Creek (fig. 1) from 25 June to 1 July 2010 . Additional samples $(n=118)$ on the downstream portion of Chicago Creek, other drainages from the Anugi prospect, upper Candle Creek, and Glacier Creek were collected from 17 to 28 June 2011. Stream water samples were collected along main channels and from tributaries, usually five to 10 meters $(\mathrm{m})$ upstream from confluences. Stream characteristics range from narrow ( 0.3 to $0.6 \mathrm{~m}$ wide) mud- to silty-bottomed channels for small tributaries at higher elevations to larger gravel and cobble-bottomed channels in main streams. The largest drainage sampled was the Inmachuk River, which is locally as much as $\sim 12 \mathrm{~m}$ wide.

Weather conditions were mostly sunny during both sampling periods, with only rare drizzle and no heavy rain. Therefore, stream discharge was only minimally impacted by direct precipitation. However, significant melting of residual snowpack occurred in stretches of several drainages during sampling and likely produced minor to significant dilute water (without significant soil or bedrock interaction) in these streams. Seeps were sampled at their point of discharge.

Water was collected in a clean 1-liter Nalgene sample collection bottle after prerinsing with site water at least three times. Three aliquots of water were drawn from the collection bottle using a disposable 60 -milliliter $(\mathrm{mL})$ syringe prerinsed with site water and filtered using a 0.45 -micrometer $(\mu \mathrm{m})$ screw-on filter. The first aliquot (AU) filled a $60-\mathrm{mL}$ bottle and was used to analyze for gold. The second aliquot (FA), for major and trace element analysis, was filtered and put into another $60-\mathrm{mL}$ bottle. The third aliquot (FU) consisted of 30 $\mathrm{mL}$ of filtered water to be used for anion analyses. To preserve samples, most FA aliquots were acidified immediately in the field using 6 to 7 drops of ultrapure nitric acid to lower the $\mathrm{pH}$ below 2.5. However, several samples from Chicago Creek were filtered and acidified in camp because all filters brought into the field clogged during onsite filtering. The AU aliquots were not acidified. All samples were stored on ice in a cooler (2010) or in a refrigerator (2011) and maintained at temperatures below 45 degrees Fahrenheit $\left({ }^{\circ} \mathrm{F}\right)$ by the evening of collection. Samples remained refrigerated until analysis. Onsite measurements included $\mathrm{pH}$, specific conductance, alkalinity, dissolved oxygen, and water temperature.

All analyses were conducted by Activation Laboratories, Ltd. Determinations of 63 cations using the FA (filtered and acidified) aliquot and of gold using the AU aliquot were completed by high resolution inductively coupled mass spectrometry (HR-ICPMS) using a Finnegan Mat ELEMENT 2 instrument. Anions were determined by ion chromotagraphy. 
For specific parameters used in our study, we refer the reader to Activation Laboratories, Ltd. (http://www.actlabs.com/).

The procedures included samples for a quality control (QC) assessment. Nalgene bottles filled with deionized water derived from the USGS ultrapure water systems were used in the field as field blanks to evaluate procedural contamination. Site duplicates were taken at nine sites to evaluate repeatability and site variation. Instrumental precision was constrained by analysis of laboratory duplicate solutions, with variation typically less than 5 percent. Activation Laboratories, Ltd., standard reference material (SRM) water standards were analyzed with sample batches to assess instrumental accuracy. The QC assessment indicates that there was minor contamination by sample processing. Some major elements and most trace elements were below detection limits at nanogram-per-milliliter $(\mathrm{ng} / \mathrm{mL})$ levels or had very low concentrations $(<12 \mathrm{ng} / \mathrm{mL})$ in the field blank samples. Only one blank sample contained a statistically anomalous metal concentration (zinc at $62 \mathrm{ng} / \mathrm{mL}$ ). Comparison of site duplicate pairs showed agreement within 20 percent for most elements and within 10 percent for some elements, with generally lesser consistency at lower $\mathrm{ng} / \mathrm{mL}$ concentrations. Spurious variations in $\mathrm{Cu}, \mathrm{Pb}$, and $\mathrm{Zn}$ concentrations characterized site duplicate samples. One duplicate set returned detectable $(0.2 \mathrm{ng} / \mathrm{mL})$ and nondetectable $(<0.1 \mathrm{ng} / \mathrm{mL})$ gold concentrations. Comparison of the SRMs with accepted values showed that almost all elements reported for the SRMs were within $\pm 5-10$ percent accuracy.

Elemental results were examined, and anomalous concentration levels for each element were established based on median of absolute deviations (MAD) added to the median (median+2MAD) to establish threshholds for anomalous concentrations (table 1). This method results in a larger number of samples characterized as above threshold (that is, anomalous values) and has been proposed to be more robust for filtering for anomalous concentrations in geologic samples than the mean plus two standard deviations (mean+2SDEV) method (for example, Reimann and others, 2005; Carranza, 2010). The number of anomalous values calculated using the median+2MAD method nonetheless can exceed the 95th percentile (for example, $\mathrm{Ag}$ and $\mathrm{Cu}$ ), lie between the 95th and 90th percentiles (for example, $\mathrm{As}, \mathrm{Mo}, \mathrm{Pb}, \mathrm{Tl}$, and $\mathrm{SO}_{4}^{2-}$ ), or fall below the 90 th percentile $(\mathrm{Cd}, \mathrm{K}, \mathrm{Sb}$, and $\mathrm{Zn})$ as a consequence of varying distributions of measured values for given elements.

\section{Results}

Summary statistics for select parameters and elemental concentrations are presented in table 1. Most of the water samples collected during this study are circumneutral, with $\mathrm{pH}$ values between 6.2 and 8.4 (median 7.45). Ten samples, including several seeps, have lower $\mathrm{pHs}$. These include samples from five sites at and near Alder Creek ( $\mathrm{pH} 2.5$ to 6.04), two samples from Gold Run Creek $(5.85,6.04)$, and one sample each from Richmond Creek (5.55), an unnamed creek to the south (5.88), and Blank Creek (5.95). Most waters with high $\mathrm{pH}$, from 8.5 to 9.6 , were collected from the marble-rich Inmachuk River-Old Glory Creek area.

The major anions in the samples range mostly from bicarbonate-dominant to sulfate-dominant (fig. 2), with sulfate concentrations spanning approximately six orders of magnitude and chloride concentrations ranging over less than two orders of magnitude. Most of the sulfate-dominant waters are from Alder Creek (near Anugi), Patterson, Limestone, and Blank Creeks (Candle area), and Nelson Creek (tributary of Old Glory Creek; fig. 1). Relatively chloride-rich (low sulfate concentration) waters are abundant in some drainages near Anugi and in the Candle area.

Calcium and magnesium are the dominant cations. The Na-K-dominant and mixed waters, largely from the Patterson, Limestone, Richmond, lower Chicago, and Alder Creek areas, have low absolute $\mathrm{Mg}, \mathrm{Ca}$, and sulfate concentrations and high $\mathrm{Al}$ and chloride contents relative to the more calcium- to magnesium-dominant waters. The Na-K-dominant waters also have $\mathrm{pH}$ values that are mostly circumneutral to weakly acidic, possibly indicating less interaction with carbonateand sulfate-bearing rocks and sediments. As a group, specific conductance values of water samples show a wide range from 12 to 1,965 microsiemens per centimeter $(\mu \mathrm{S} / \mathrm{cm})$ and correlate with measured $\mathrm{Ca}, \mathrm{Mg}$, and sulfate concentrations.

\section{Baseline Samples}

One sample of snowpack and two samples of seawater from the nearby shoreline were collected to establish the chemistry of snow and seawater, and these were not included in the overall statistical treatment of the water sample dataset. The snowpack sample, collected on Gold Run Creek (fig. 1), is interpreted to represent the chemical composition of waters that have had no contact with geologic materials. Most elements in this sample had concentrations near or below the detection limit, although zinc $(26 \mathrm{ng} / \mathrm{mL})$ occurred at an anomalous concentration.

The two seawater samples were collected to assess whether ocean spray could influence stream chemistry of our more inland sites. Influence of ocean-sourced gold is of particular interest, in light of variable concentrations of gold $[\mathrm{Au}]$ reported in seawater, from 1 to 50 parts per trillion (ppt) or 1 to $50 \mathrm{ng} / \mathrm{L}$ (Nekrasov, 1996), which is 10 to 500 times the detection limit of our method $(0.1 \mathrm{ng} / \mathrm{L})$. However, Au in our seawater samples was below the detection limit. Major element concentrations were generally consistent, but trace element results varied between the two samples, possibly related to sampling within the swash zone along shore and postulated inclusion of colloidal material smaller than $0.45 \mu \mathrm{m}$ in the sample. Seawater Ag, As, Ca, Cd, K, Li, Mg, Na, $\mathrm{Rb}, \mathrm{Sb}, \mathrm{Sr}$, and $\mathrm{U}$ concentrations fall within the upper quartile or exceed those in terrestrial water samples (table 1), and thus they could influence water analyses near the coast. However, the lack of elevated concentrations of elements like $\mathrm{K}, \mathrm{Na}$, or chlorine in stream and seep samples closest to the shoreline suggest that the influence of sea spray is minimal. 


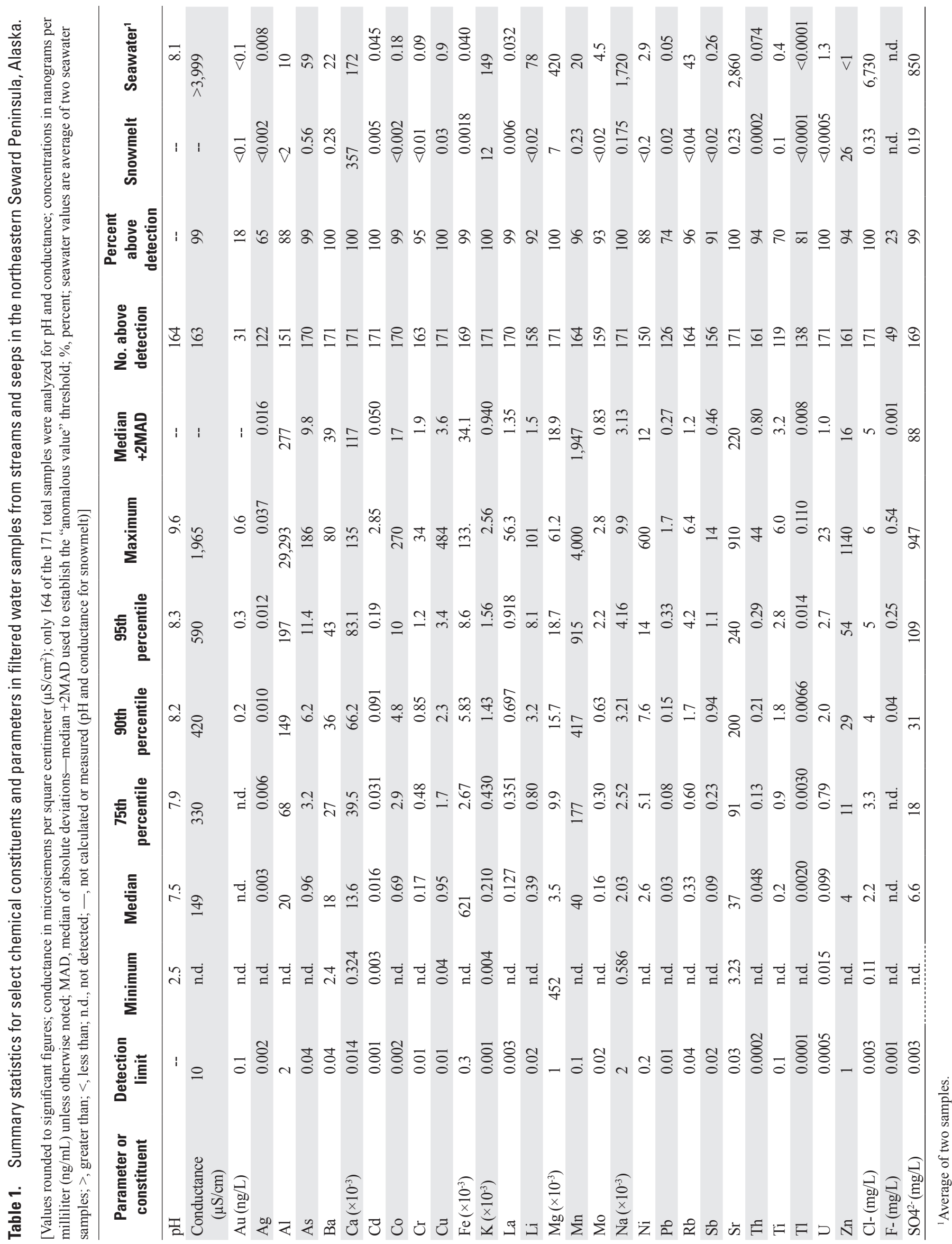




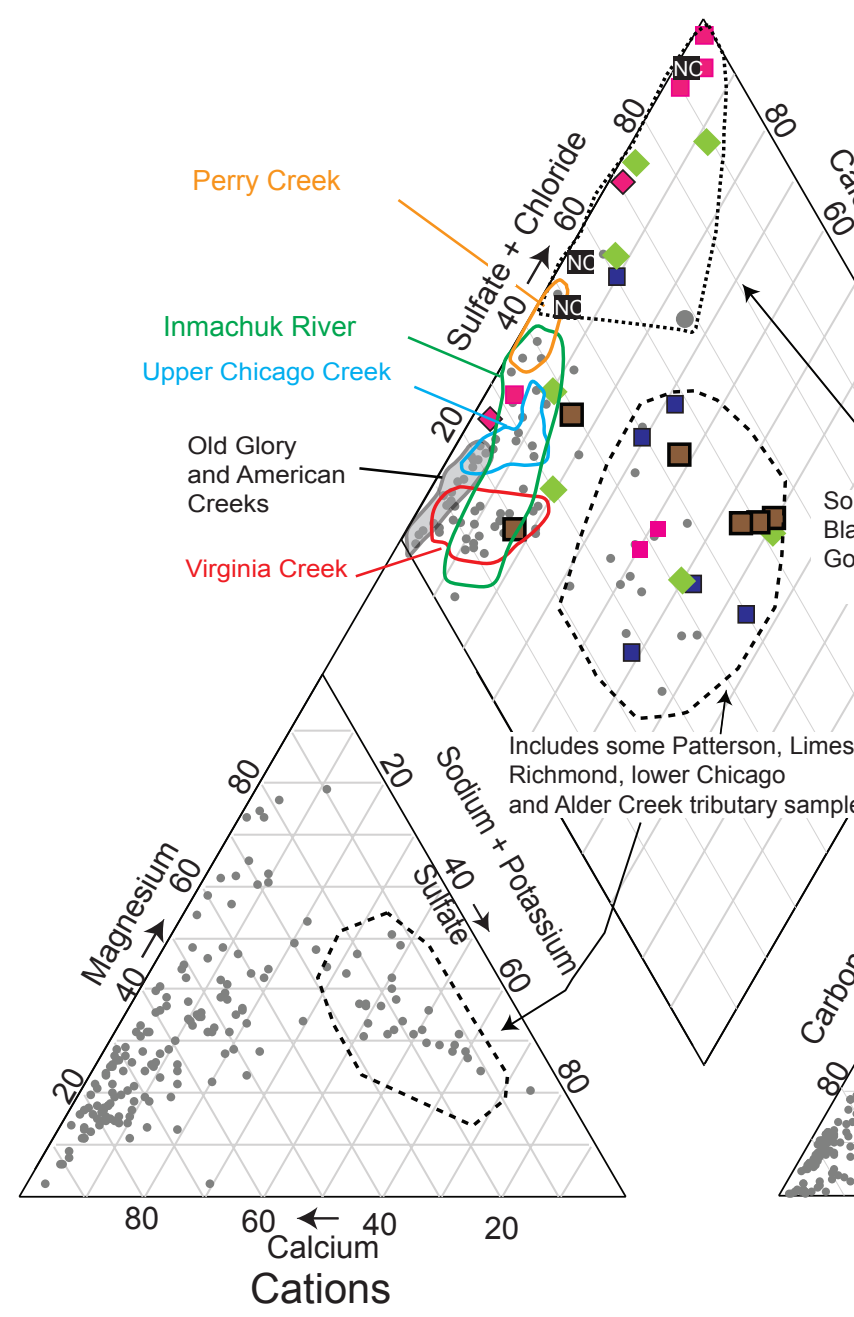

NC Nelson Creek drainage

- Alder Creek drainage

$\square$ Richmond Creek drainage

- Patterson Creek drainage

$\diamond$ Blank Creek drainage

- Limestone Creek drainage

Zn-bearing sample on Gold Run Creek

\section{Gold Distribution}

Geographically, gold is the most widely distributed of the potential ore-related elements considered in this study (fig. $3 A$ ), even though in more than 80 percent of the samples Au was not detected. Low values ( 0.1 to $0.2 \mathrm{ng} / \mathrm{L}$ ) were measured in multiple samples collected upstream of historical placer workings on Old Glory Creek and as point anomalies upstream of placer workings on multiple streams in the Candle Creek area and on Gold Run Creek (Monument Mountain area). The highest concentrations were measured in a seep along Old Glory Creek $(0.6 \mathrm{ng} / \mathrm{L} \mathrm{Au})$ and in multiple samples from upper Chicago Creek (0.2 to $0.6 \mathrm{ng} / \mathrm{L} \mathrm{Au})$ collected during the 2010 field season. However, two of the sites along Chicago Creek, when revisited during the 2011 field season, produced samples that did not yield detectable Au concentrations.

\section{Anugi Prospect Area}

Water samples from around the Anugi $\mathrm{Pb}-\mathrm{Zn}-\mathrm{Ag}$ prospect, including Alder Creek and Chicago Creek, contain elevated concentrations of many trace elements, including Ag, As, Cd,
$\mathrm{Pb}$, and $\mathrm{Zn}$. The highest concentrations of several of these elements occur in waters from east- or north-draining streams at or near the Anugi $\mathrm{Pb}-\mathrm{Zn}-\mathrm{Ag}$ prospect (figs. $3 B-F$ ). Very high $\mathrm{Cd}$ concentrations, commonly with concomitant high $\mathrm{Zn}$ concentrations, occur in parts of multiple eastward-draining streams (figs. $3 D, F$ ). The most laterally extensive multielement anomaly also includes Ag (fig. 3B), As (fig. 3C), and scattered anomalous thallium ([Tl]; fig. $3 G$ ) concentrations above the median $+2 \mathrm{MAD}$ threshold in the southern headwater tributary of Virginia Creek. To the west of Anugi in Chicago Creek, $\mathrm{Cd}$ and $\mathrm{Zn}$ concentrations are not anomalous, and anomalous arsenic and thallium concentrations only occur close to the Anugi deposit. This drainage and its tributaries contained widespread Au detections (mostly at 0.3 to $0.6 \mathrm{ng} / \mathrm{L}$ ) in samples from 2010 (fig. $3 A$ ).

Waters from Alder Creek, approximately $2 \mathrm{~km}$ northwest of Anugi, contain anomalous concentrations of $\mathrm{Cd}, \mathrm{Co}, \mathrm{Cu}, \mathrm{Fe}, \mathrm{Mn}, \mathrm{Ni}, \mathrm{Tl}$, and $\mathrm{Zn}$. Some of the highest concentrations of metals measured in this study were measured in a sample from a low $\mathrm{pH}$ seep in that area. Lower but anomalous concentrations of several metals, including $\mathrm{Cd}, \mathrm{Tl}$, and $\mathrm{Zn}$, extend the full $1.6 \mathrm{~km}(1 \mathrm{mile})$ extent sampled in the main creek (fig. 3). Gold was detected at one location on Alder Creek (fig. $3 A$ ). 

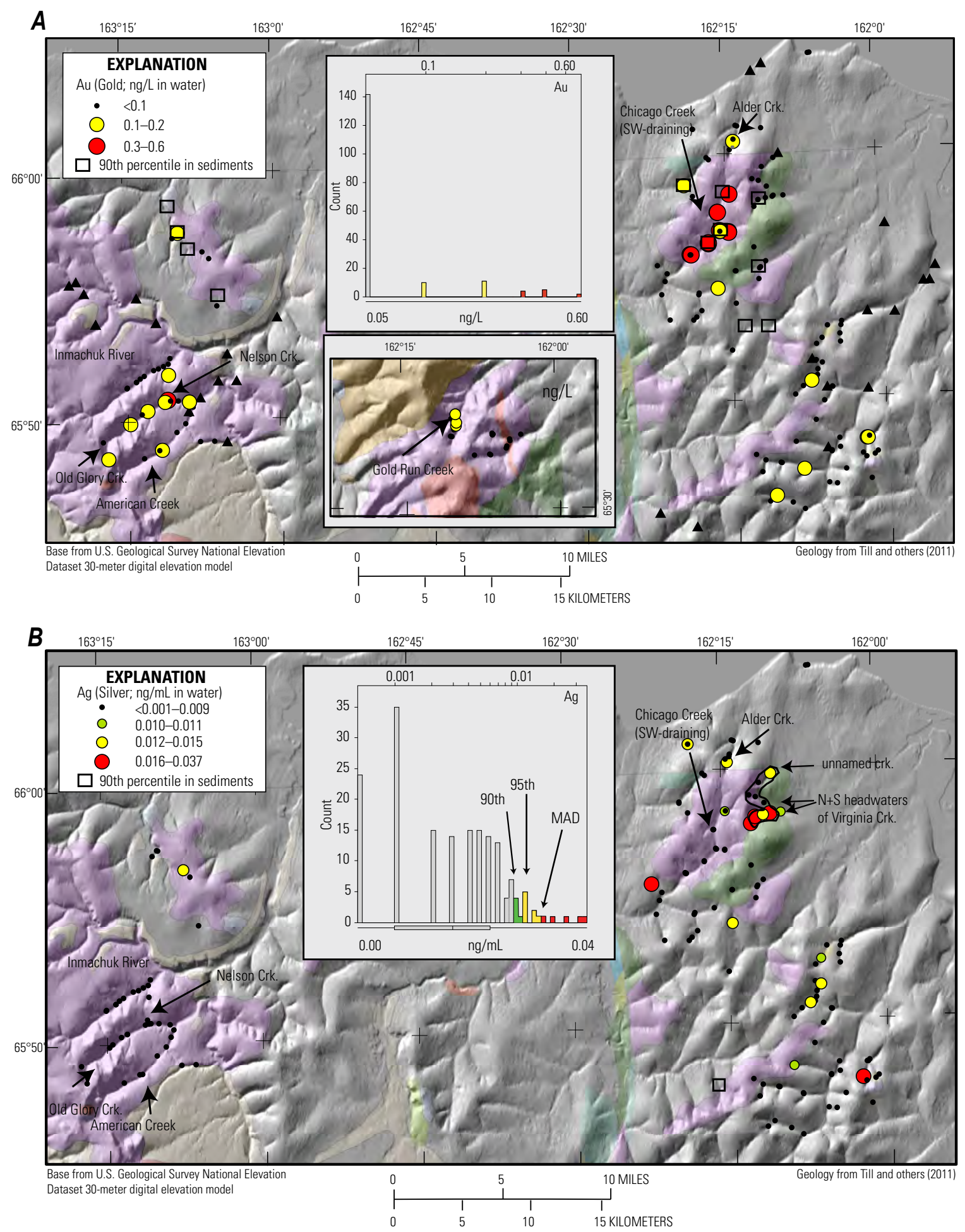

Figure 3. Maps showing locations of anomalous metal concentrations in water samples from study area, northeastern Seward Peninsula, Alaska. A, Gold (Au). B, Silver (Ag). C, Arsenic (As). D, Cadmium (Cd). E, Lead (Pb). F, Zinc (Zn). G, Thallium (TI). H, Molybdenum (Mo). I, Antimony (Sb). Black squares and polygons represent areas containing metal concentrations greater than the 90th percentile in stream sediment samples (NANA Regional Corporation, unpublished data). Black triangles in $A$ mark locations of mineral occurrences shown in figure 1. See figure 1 for explanation of colors representing geologic units. Inlays of frequency histograms show distribution of concentrations in nanograms per liter (ng/L) or nanograms per milliliter $(\mathrm{ng} / \mathrm{mL})$; all but Au also show median plus twice the median of absolute deviations (median+2MAD) and 90th and 95th percentile divisions. Inset maps for the Monument Mountain area show the distribution of Mo and Au concentrations; all other elements yielded no values in that area above detection limits. 


\section{C}

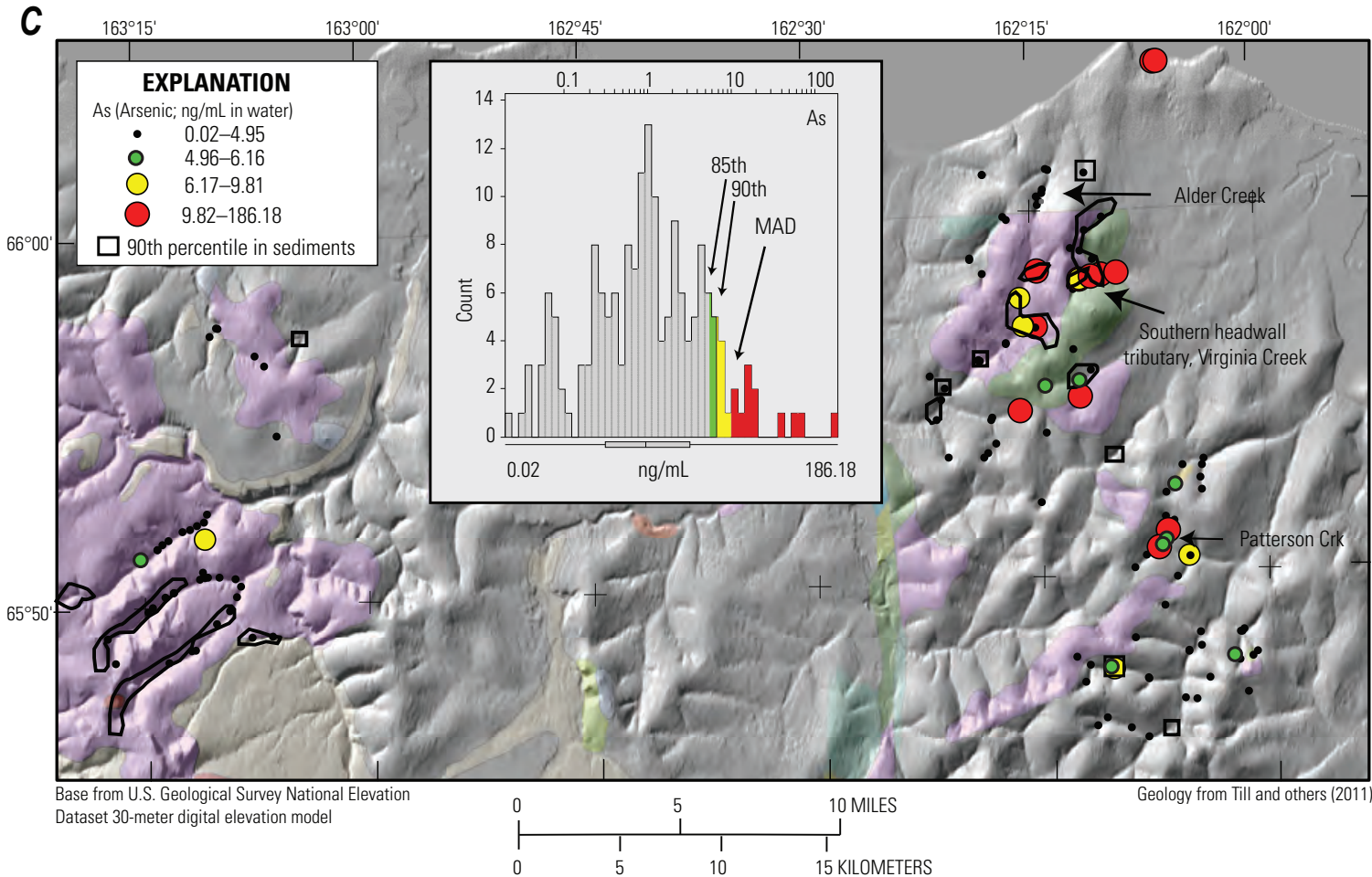

D

$163^{\circ} 00^{\prime}$

$162^{\circ} 45^{\prime}$

15 KILOMETERS

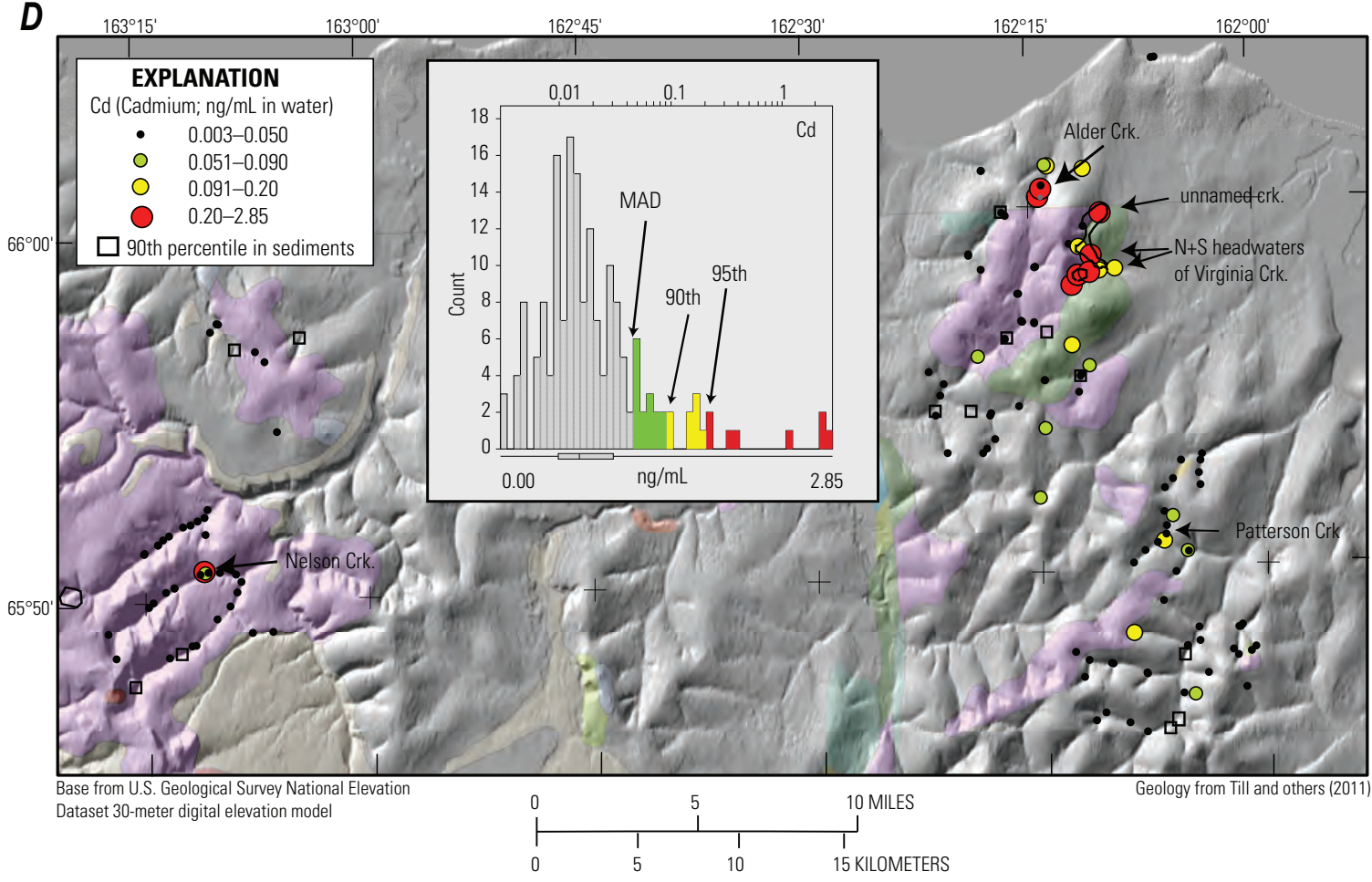

Figure 3.-Continued 

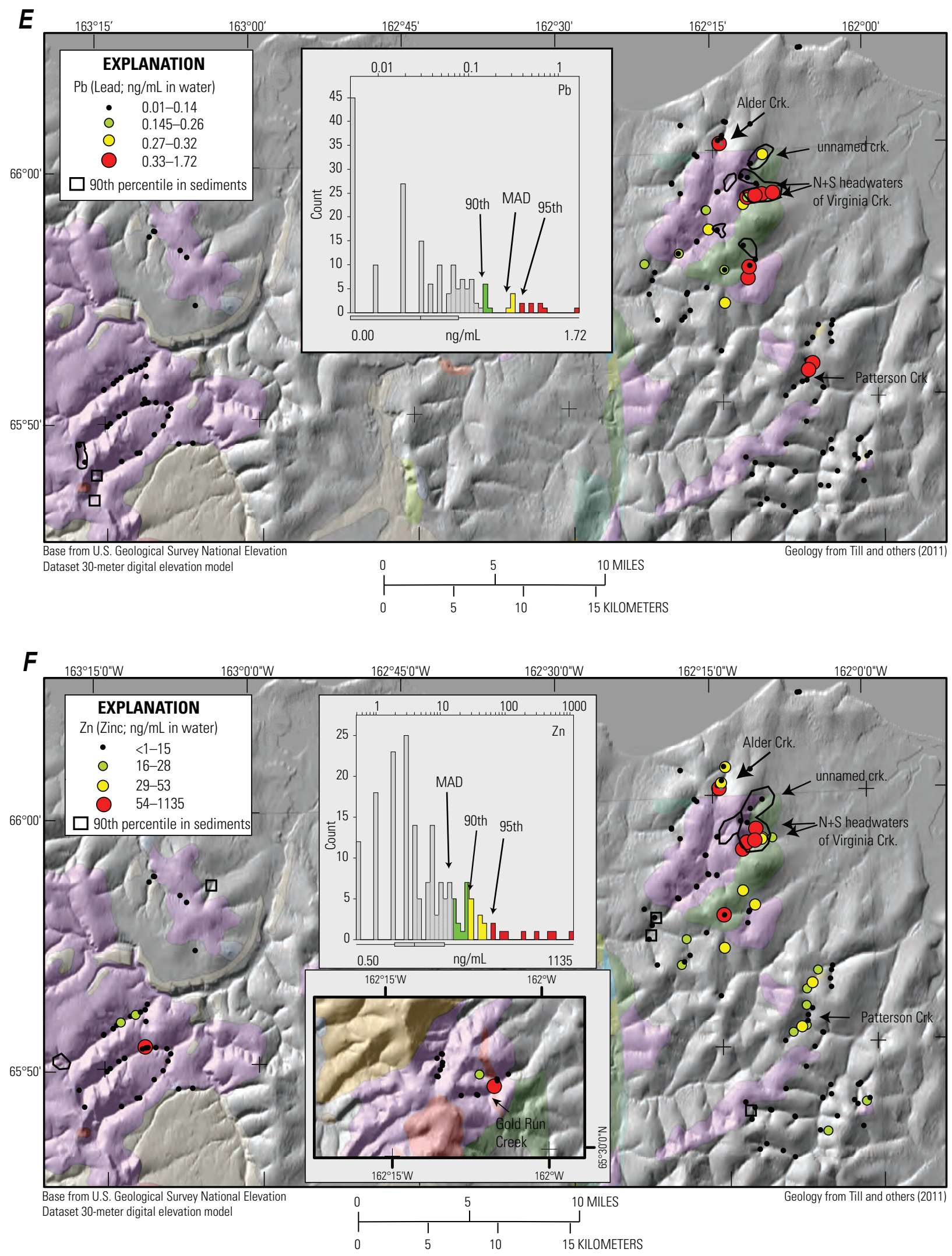

Figure 3.-Continued 

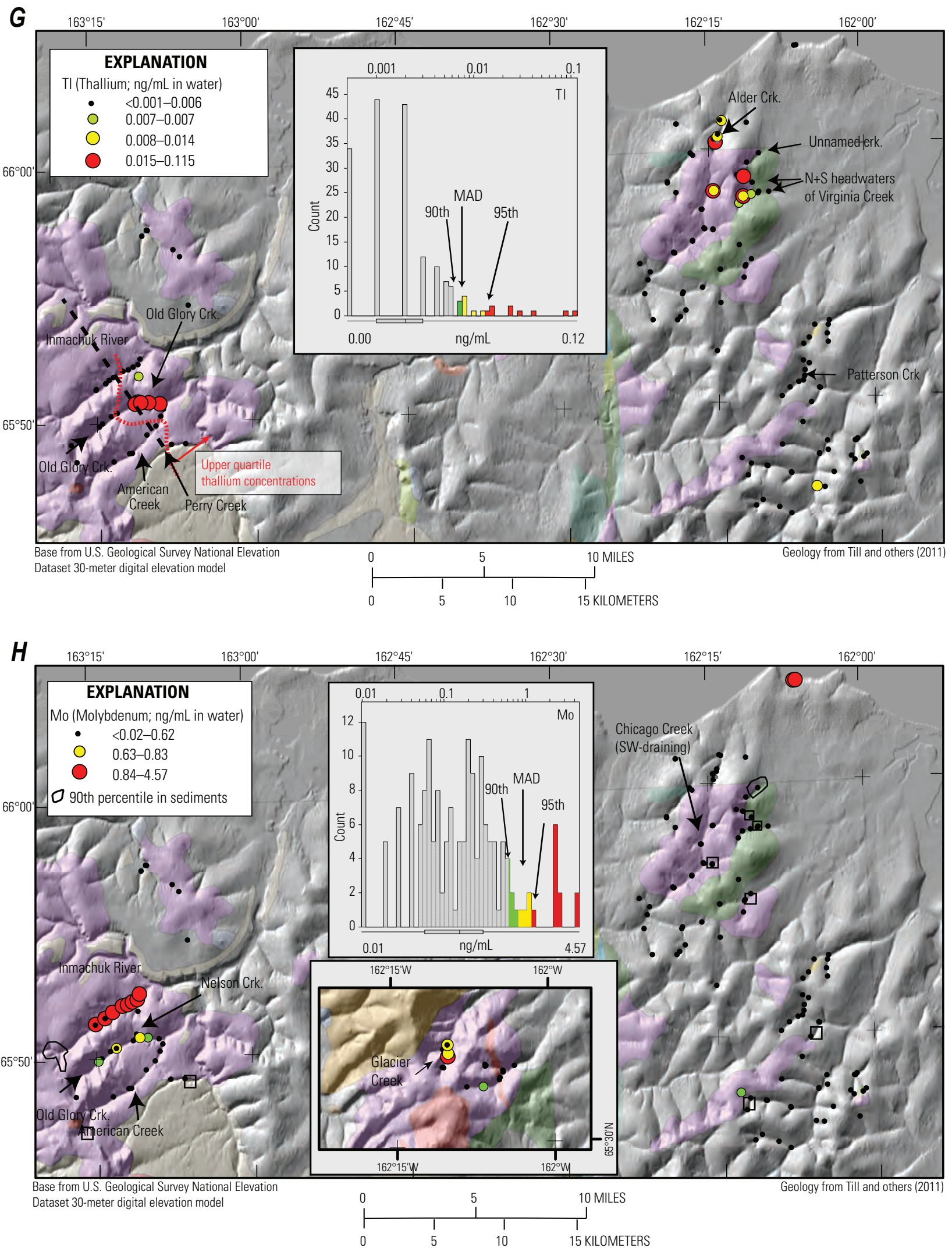

Figure 3.-Continued 


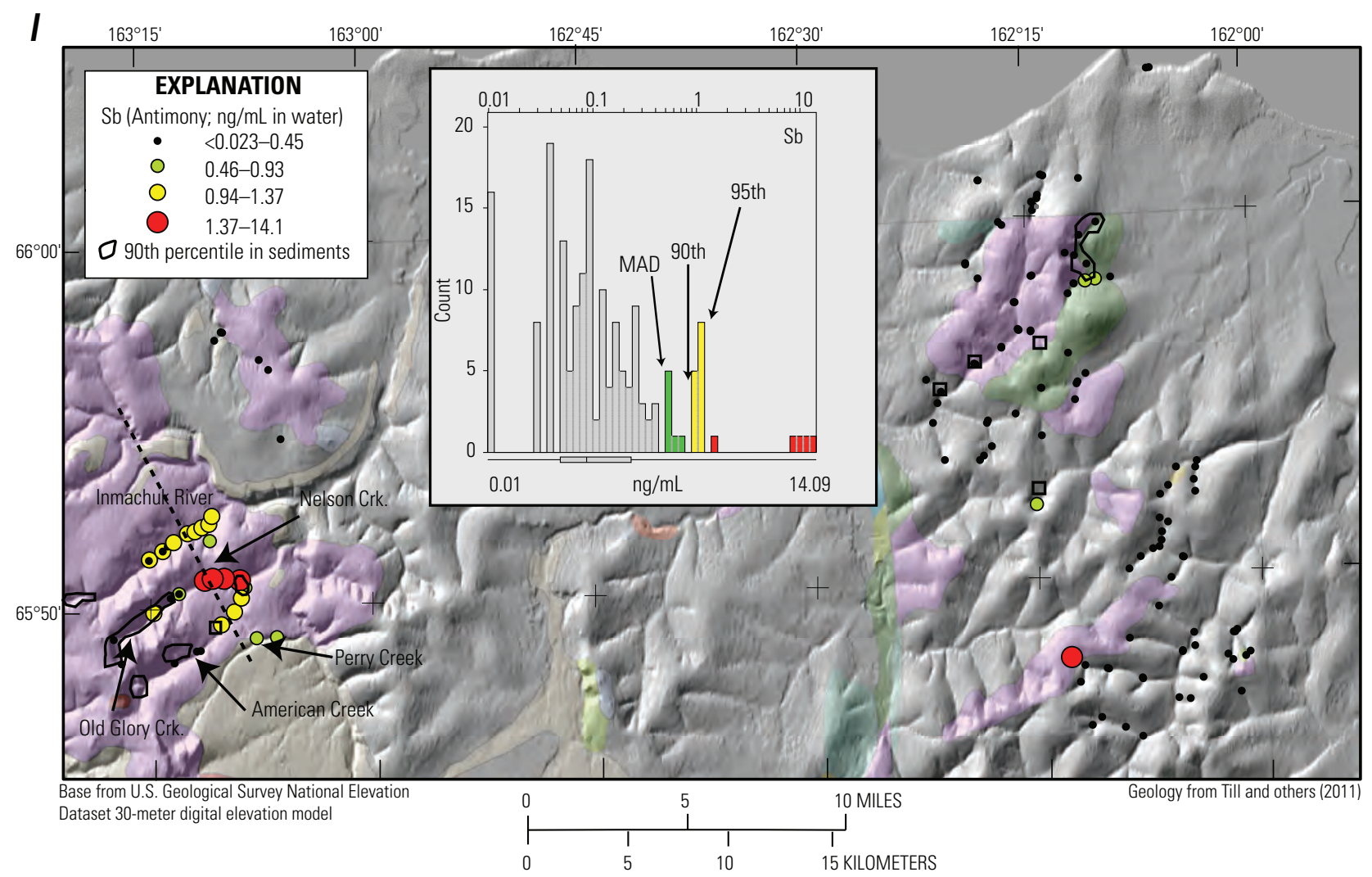

Figure 3.-Continued

\section{Candle Area}

Sporadic anomalous concentrations of metals were measured in some waters from the Candle area. Patterson Creek in particular yielded samples with elevated $\mathrm{Ag}, \mathrm{As}, \mathrm{Cd}$, and $\mathrm{Pb}$ concentrations (figs. $3 B, C, D, E$ ). A single sample contained detectable $\mathrm{Au}$ and $\mathrm{Tl}$ (figs. $3 A, G$ ). Notably, if an 85th-percentile cutoff for anomalous As concentrations is employed, five contiguous sites in upper Patterson Creek would be identified. Other point anomalies exist elsewhere in this region, including in Limestone and Blank Creeks.

\section{Inmachuk River-OId Glory Area}

Water from the Inmachuk River-Old Glory area contains mostly upper quartile $\mathrm{Ca}, \mathrm{Mg}$, and $\mathrm{K}$ concentrations. Highest concentrations of these elements, along with fluorine, occurred mostly in samples from the Inmachuk River, whose volume was predominantly derived from a large seep emanating from a highly fractured zone of marble at approximately the farthest upstream (southwesternmost) sampling site. Nearly the entire Inmachuk River and parts of Old Glory drainages also yielded anomalous concentrations of $\mathrm{Sb}$ (fig. 3I), Mo (fig. 3H), and $\mathrm{W}$. Most samples with detectable concentrations of $\mathrm{Au}$ of 1 to $2 \mathrm{ng} / \mathrm{L}$ (detection limit of $1 \mathrm{ng} / \mathrm{L}$ ) are from sites within the Old Glory Creek drainage (fig. $3 A$ ). Concentrations of $\mathrm{Sb}$ and
$\mathrm{Tl}$ along Old Glory Creek increase by greater than an order of magnitude near and downstream of the confluence with Nelson Creek, increasing from $\sim 0.5 \mathrm{ng} / \mathrm{mL} \mathrm{Sb}$ and $<0.001 \mathrm{ng} / \mathrm{mL} \mathrm{Tl}$ to $10-14 \mathrm{ng} / \mathrm{mL} \mathrm{Sb}$ and $0.025 \mathrm{ng} / \mathrm{mL}$ Tl with distance downstream (fig. 3G, I). Less anomalous concentrations also occur in the adjacent, subparallel American Creek. Samples from two seeps - one each on Eureka Creek and Nelson Creek-contain detectable $\mathrm{Au}$. Eureka Creek contains anomalous $\mathrm{Sb}$ (along with arsenic and bismuth [Bi]) and 90th percentile $\mathrm{Tl}$, whereas the Nelson Creek seep, situated in ground disturbed by historical placer mining, contains elevated $\mathrm{Cd}, \mathrm{Tl}$, and $\mathrm{Zn}$ concentrations (fig. $3 D, F, H$ ).

\section{Glacier and Gold Run Creeks}

Water samples collected upstream of placer operations on Glacier and Gold Run Creeks contain nearly ubiquitous elevated $\mathrm{K}$ concentrations, similar to those from the Inmachuk River, but few of them contain anomalous concentrations of metals. Three slightly alkaline seep samples ( $\mathrm{pH} \sim 7.6)$ on the southeastern branch of Glacier Creek have concentrations of Mo of $\sim 1.2 \mathrm{ng} / \mathrm{mL}$ (fig. $3 H$ ). Two of these samples (and a third from near the confluence of the headwater streams) contain 0.1 to $0.2 \mathrm{ng} / \mathrm{L} \mathrm{Au}$ (fig. $3 A$ ). An anomalous zinc concentration $(189 \mathrm{ng} / \mathrm{mL})$ is present in a sample from a seep on Gold Run Creek (fig. $3 F$ ). 


\section{Discussion}

\section{Comparison of Hydrogeochemical Data with Historical Stream Sediment Data}

Areas of anomalous metal concentrations in stream sediments (90th percentile cutoff; NANA Regional Corporation, unpublished data) are outlined in figure 3. Closely spaced sediment samples exist for Anugi, the western Candle Creek area, including Patterson Creek, and parts of the Inmachuk River-Old Glory Creek area; relatively more widely spaced samples are characteristic of other areas. In the Anugi area, these data yield multipoint $\mathrm{Ag}, \mathrm{As}, \mathrm{Cd}, \mathrm{Pb}$, and $\mathrm{Zn}$ anomalies in the northern and southern headwater tributaries for Virginia Creek and in an unnamed creek to the north. The anomalous sediments are spatially more broadly distributed than our water data, which show highest concentrations of the suite of elements mostly in the southern headwater tributary of Virginia Creek. Cadmium is the only element that displays similarly distributed widespread elevated concentrations in both sets of data (fig. $3 D$ ). To the north in Alder Creek, sediment samples lack anomalous concentrations of metals (figs. 3A-I).

Sediment geochemistry from the Inmachuk River-Old Glory area indicates sporadically anomalous $\mathrm{Sb}$ concentrations throughout upper Old Glory and American Creeks, in contrast to the wide distribution of high concentrations of $\mathrm{Sb}$ (and $\mathrm{Tl}$ ) in waters from below the confluence with Nelson Creek (figs. $3 G$, I). Sediment data were not collected for the same stretch of the Inmachuk River included in our study and instead are restricted to the southwest (upstream) stretch; however, elevated concentrations of $\mathrm{Mo}$ and $\mathrm{Sb}$ in those sediments are consistent with high concentrations of these metals observed in our water samples (see, for example, figs. $3 H, I$ ). The absence of $\mathrm{Tl}$ analyses and high detection limit for $\mathrm{W}$ in sediment geochemistry results (yielding censored data) from the Inmachuk River, as well as sparse regional historical sediment geochemistry data elsewhere in the study area, preclude comparison of geochemistry of water and sediments.

The distribution of detectable Au concentrations in waters is different but spatially overlaps with elevated gold values in stream sediments (using 10 parts per billion [ppb] cutoff). Detectable $\mathrm{Au}$ in waters from Old Glory Creek and in the Candle area do not have coincident sediment anomalies. Conversely, multiple $>10 \mathrm{ppb}$ values in sediments from the Iron Creek area and south of Anugi mostly are not coincident with water samples having detectable gold. However, both sets of samples contain elevated $\mathrm{Au}$ concentrations throughout much of the Chicago Creek drainage (fig. $3 A$ ).

\section{Effectiveness of $\mathrm{Pb}-\mathrm{Zn}-\mathrm{Ag}$ Deposit Detection Anugi Region}

High concentrations of metals, including $\mathrm{Pb}, \mathrm{Zn}, \mathrm{Ag}, \mathrm{As}$, and $\mathrm{Tl}$, in many water samples from Anugi are derived from the $\mathrm{Pb}-\mathrm{Zn}$-Ag-As-mineralized bedrock near the ridge top. The combined pathfinder suite is consistent with hydrogeochemical studies around other $\mathrm{Pb}-\mathrm{Zn}-\mathrm{Ag}$ deposits hosted in sedimentary and volcanic rocks (Leybourne and Cameron, 2010), including some in northern Alaska (for example, Red Dog, Drenchwater, and Lik; Kelley and Taylor, 1997). However, areas of highest metal concentrations in waters (southern headwater tributary of Virginia Creek) are not coincident with areas of high metal concentrations in sediments that occur farther north.

The varied water chemistry in the Anugi area may relate to differing influence of dilute meltwater on bulk stream water chemistry in different drainages. The southern headwater tributary drainage contained only minor residual winter snowpack (and thus melt water), whereas drainages to the north contained the greatest snowpack observed anywhere in the study area during sampling. Presumably some base flow of percolated metalliferous waters owing to interaction with mineralized soils, stream sediments, or bedrock was present in all streams, as indicated by sediment data. However, greater amounts of meltwater in the northern headwater stream at the time of sampling likely diluted metal concentrations compared to those in the southern drainage.

The metalliferous seep and stream waters collected along the main channel of Alder Creek suggest additional geochemically similar basemetal-mineralized rock in this area. However, given the absence of anomalous metals in sediments from Alder Creek, it is likely that the source of metals is either beneath or lateral to the current stream channel. If this is the case, water chemistry may provide the only evidence of concealed mineralized rock. Alternatively, the mineralized bedrock through which spring water originally flowed could be of insufficient size or grade to generate elevated concentrations of metals in bulk stream sediments. Further study is required to delineate the location and extent of mineralized rock.

\section{Interpretations of Inmachuk River-0Id Glory Creek Data}

The abundant trace metal anomalies in the waters of the Inmachuk River-Old Glory Creek area are suggestive of two different types of mineralized bedrock - the first is characterized by anomalous $\mathrm{K}, \mathrm{Mo}, \mathrm{W}$, and high fluorine (not shown) concentrations in the main channel of the Inmachuk River, and the second is reflected by marked increases in antimony and thallium, best demonstrated on Old Glory Creek. The geochemical signature of Inmachuk River samples is consistent with interaction of the water with quartz-fluorite veins with elevated molybdenum, which were previously reported in the veins at the nearby Crossfox Butte syenite (fig. 1; Gamble, 1988). Therefore, the water chemistry is likely reflecting a concealed, possibly granite-hosted Mo occurrence to the west or northwest of the river. Anomalous $\mathrm{Sb}$ concentrations suggest that this system may be Sb-rich, or that spring waters had interacted with other, Sb-rich rocks. 
The highly anomalous concentrations of $\mathrm{Sb}$ and $\mathrm{Tl}$ in waters from Old Glory Creek near the confluence with Nelson Creek indicate an abrupt change in bedrock chemistry as the consequence of lithologic changes or mineralization. The latter is suggested based on reported Au-and Sb-mineralized bedrock and float in the area (Herreid, 1966; Hawley 2007). The high Sb concentrations in lower American Creek versus those in its upper reaches, as well as anomalous concentrations in the two samples on Perry Creek suggest that Sb-rich rocks continue to the southeast. Although anomalous $\mathrm{Tl}$ concentrations are mostly restricted to the Old Glory Creek drainage, samples containing Tl concentrations above the 75 th percentile (upper quartile) are distributed in same locations as those containing anomalous $\mathrm{Sb}$, suggesting a geochemical association (bedrock-bearing $\mathrm{Sb}$ and $\mathrm{Tl}$ ) (dashed line, fig. 3G). To the north, upper quartile Tl concentrations are present in the lower Inmachuk River, but without coincident abrupt increases in Sb, suggesting a northwestward extent of a Tl source. Either Sb-rich rocks are not present here, or the inherent elevated concentrations of Sb in upstream Inmachuk River samples may act to mask influence of such rocks. Nonetheless, our geochemical results support the presence of a northwest-trending mineralized zone (fault zone?) that cuts across all drainages, as proposed by Hawley (2007). The zone can tentatively be projected toward the mineral deposits and occurrences in the Hannum Creek area. The nature of the zone is uncertain but it could have played a role in the genesis or current distribution of exposures of base- and precious-metal deposits in these two areas.

The significance of elevated $\mathrm{Tl}$ in water samples may be explained in multiple ways. Although $\mathrm{Tl}$ is not reported as an important pathfinder element for orogenic or intrusion-related gold systems, it is a key element (along with antimony) in Carlin-type deposits (see, for example, Cline and others, 2005). Conversely, if $\mathrm{Pb}-\mathrm{Zn}$ prospects at Hannum Creek (not examined in this study) are characterized by elevated Tl, as is the case at the Anugi lead-zinc prospect, the high thallium concentrations could record leaching of $\mathrm{Tl}$ from $\mathrm{Pb}-\mathrm{Zn}$ mineralized zones by waters and movement along the proposed structure into the Inmachuk River-Old Glory area.

\section{Interpretations of Candle Area and Monument Mountain Area Data}

The sporadic distribution of elevated metal concentrations in most of the Candle area water samples most likely indicates that large underlying occurrences of base or precious metals do not exist. However, the two nonadjacent samples on Patterson Creek that contain anomalous As (at the 90th percentile) and one with detectable Au are significant because arsenopyrite-bearing veins and arsenopyrite in heavy-mineral concentrates were reported from this drainage (Hudson, 1999), and gold commonly occurs with arsenopyrite. The contiguous five sites delineated by an 85th-percentile cutoff for As (fig. 3C) support this observation, and they would form the only broad As anomaly in the Candle area. Single-site anomalies of detectable Au and sulfate occur on Blank Creek and gold-only anomalies in the southern Candle area, but whether they reflect locally sulfidic, gold-bearing zones is uncertain.
Localized $\mathrm{Zn}$-bearing seeps with relatively low $\mathrm{pH}$ (for example, Limestone Creek in the Candle Area and Gold Run Creek in the Monument Mountain Area) could reflect underlying base metal accumulations. Anomalous $\mathrm{Pb}, \mathrm{Zn}$, or Ag were not detected in water samples despite a reported anomalous base metal anomaly on Glacier Creek in the Monument Mountain area (Hudson, 1999). The three detectable $\mathrm{Au} \pm \mathrm{Mo}$ concentrations in the headwaters of Glacier Creek delineate a prospective target for gold because of their lateral extent (figs. $3 A, G$ ).

\section{Possible Geologic Controls on Observed Hydrochemistry}

Water chemistry is controlled by the extent of interaction with one or more compositionally different geologic materials. Bulk water chemistry reflects the mixing of multiple waters, as well as the reactions that result from this mixing. The polymetallic Anugi occurrence lies near the ground surface and has a large footprint that is cut by three streams, which helped to enhance identification of anomalies in our survey. The large footprint compensated for the variation in metal concentrations observed in different drainages, which we attribute to greater or lesser influence of dilute meltwater on observed chemistry. Notably, if sampling had occurred during, and not after, major melting of snow in the southern headwater tributary of Virginia Creek, the distinct hydrogeochemical anomaly may have been diluted and not recognized in our survey.

If proximal orogenic or intrusion-related gold veining is responsible for all or some placer deposits in the study area, the morphology and mineralogy of these mineralizing systems, and thus the hydrogeochemical signatures from these deposits, would be different from that of Anugi. Quartz veins in the orogenic or intrusion-related gold deposits can occur in large (meters-scale) shear zones or form small sheeted or stockwork vein systems that could manifest different distributions and concentrations of pathfinder elements. Furthermore, both orogenic and intrusion-related gold systems can contain low total volumes of sulfide ( $<5$ percent, commonly pyrite and arsenopyrite) and can have limited alteration halos (Goldfarb and others, 2005). Useful pathfinder elements like selenium (Se), As, and Sb (see, for example, Cidu and others, 1995; Leybourne and Cameron, 2010) might then be present at lower absolute concentrations or occur in more restricted geographic areas (narrow veinlets) than observed at Anugi. These factors could limit the opportunity for waters to interact with mineralized rock and also make them more susceptible to dilution by unreacted waters. Unless sampling occurs along a mineralized vein or in an area of concentrated mineralized veins that are naturally or artificially exposed, observable geochemical anomalies may have limited lateral extent. Furthermore, when combining results from sampling in several deposit areas, high concentrations of elements in one deposit type may mask otherwise identifiable geochemical signatures from another by raising the statistical anomalous concentration threshold. This is exemplified by the high As concentrations in some samples from Anugi that preclude recognition of possible significance of elevated concentrations of arsenic in waters from Patterson Creek. 
The widespread distribution of detectable Au in water samples across the study area did not correspond to those of pathfinder elements in our study. However, empirically, many of the gold anomalies occur in geographic areas known to contain placer gold (for example, Nelson Creek seep, Patterson Creek, Candle Creek, Monument Mountain). In other cases, detectable gold in water corresponds to relatively elevated values measured in stream sediments, such as in Chicago Creek. In yet other cases like upper Old Glory Creek, the relatively high gold concentrations are more difficult to explain. Greater constraints on underlying geology are needed to interpret the significance of gold detections in water.

Our sampling was restricted to early summer; therefore, it is not possible to assess whether this is the optimal time of year for hydrogeochemical studies. However, observations of metal concentrations in streams with varying snow content at Anugi, and low metal concentrations in creeks with abundant snowpack in their headwaters, coupled with higher metal concentrations in seeps suggest that (1) seeps are the ideal sample media and (2) sampling should be conducted as late in the summer as possible, but while stream flow is ongoing. Under these conditions, overland flow from snowmelt would be minimized while contributions of water that interact with rock and soil would be maximized.

\section{Conclusions}

Results of water samples analyzed by high resolution inductively coupled mass spectrometry (HR-ICPMS) reveal several distinct geochemical patterns in poorly exposed bedrock areas of the northeastern Bendeleben quadrangle on Alaska's Seward Peninsula. Known base-metal mineralization at Anugi and prospective bedrock sources for placer gold deposits in the Inmachuk River-Old Glory, Candle, and Monument Mountain areas are reflected in our data. The hydrogeochemical signature of known $\mathrm{Pb}-\mathrm{Zn}$-Ag-mineralized bedrock at Anugi demonstrates the complex processes required to generate (and hide) evidence of mineralized rock, including water interaction with soil and bedrock and subsequent dilution by snowmelt. Conversely, metalrich waters from Alder Creek suggest the presence of concealed mineralized rock that would go unrecognized by standard streamsediment sampling.

The most laterally persistent anomalous concentrations of metals are in waters from the Inmachuk River-Old Glory Creek area. Our sampling identified anomalous $\mathrm{Sb}$ and $\mathrm{Tl}$ in multiple creeks that suggest the existence of a much more extensive, northwest-trending and possibly structurally controlled (gold-bearing?) zone that extends beyond the Old Glory Creek drainage. Highly anomalous Mo values also indicate potential for molybdenum-bearing veins to the west and northwest of the Inmachuk River. Multiple As $\pm \mathrm{Au}$-bearing water samples in upper Patterson Creek provide the best evidence of possible bedrockhosted gold in the Candle area. More sporadic metal anomalies in the Candle and Monument Mountain areas are difficult to assess but could reflect more diffuse, vein-hosted gold or less extensive water-rock interaction.
The results of our hydrogeochemical survey were successful in delineating several target areas for further exploration. Additional geochemical sampling of soil and bedrock could elucidate the causes and significance of elevated metal concentrations identified in the different areas covered in this study.

\section{References Cited}

Anderson, E., 1947, Mineral occurrences other than gold deposits in northwestern Alaska: Alaska Territorial Division of Mines Pamphlet 5-R, 48 p.

Apodaca, L.E., 1992, Fluid-inclusion study of the Rock Creek area, Nome Mining District, Seward Peninsula, Alaska, in Bradley, D.C., and Dusel-Bacon, C., eds., Geologic studies in Alaska by the U.S. Geological Survey, 1991: U.S. Geological Survey Bulletin 2041, p. 3-12.

Armstrong, R.L., Karkal, J.E., Forbes, R.B., Evans, B.W., and Thurston, S.P., 1986, Rb-Sr and K-Ar study of metamorphic rocks of the Seward Peninsula and southern Brooks Range, Alaska, in Evans, B.W., and Brown, E.H., eds., Blueschists and eclogites: Geological Society of America Memoir 176, p. 185-203.

Ayuso, R.A., and Till, A.B., 2014, Geochemical and Nd-Sr-Pb isotopic evolution of metabasites from rifting of continental lithosphere, Seward Peninsula, Alaska, and implications for paleogeographic reconstruction: Geological Society of America Special Paper 506, p. 133-172, doi:10.1130/2014.2506(05).

Carranza, E.J.M., 2010, Mapping of anomalies in continuous and discrete fields of stream sediment geochemical landscapes: Geochemistry-Exploration, Environment, Analysis, v. 10, p. 171-187, doi:10.1144/1467-7873/09-223.

Cidu, R., Fanfani, L., Shand, P., Edmunds, W.M., Van’t Dack, L., and Gijbels, R., 1995, Hydrogeochemical exploration for gold in the Osilo area, Sardinia, Italy: Applied Geochemistry, v. 10, p. 517-530, doi: 10.1016/0883-2927(95)00022-4.

Cline, J.S., Hofstra, A.H., Muntean, J.L., Tosdal, R.M., and Hickey, K.A., 2005, Carlin-type gold deposits in Nevada; critical geologic characteristics and viable models: Economic Geology 100th Anniversary Volume, p. 451-484.

Eppinger, R.G., Fey, D.L., Giles, S.A., Kelley, K.D., and Smith, S.M., 2012, An exploration hydrogeochemical study at the giant Pebble porphyry $\mathrm{Cu}-\mathrm{Au}-\mathrm{Mo}$ deposit, Alaska, USA, using high resolution ICP-MS: Geochemistry-Exploration, Environment, Analysis, v. 12, p. 211-226.

Eppinger, R.G., Fey, D.L., Giles, S.A., Grunsky, E.C., Kelley, K.D., Minsley, B.J., Munk, L., and Smith, S.M., 2013, Summary of exploration geochemical and mineralogical studies at the giant Pebble porphyry Cu-Au-Mo deposit, Alaska; implications for exploration under cover: Economic Geology, v. 108, p. 495-527, doi:10.2113/econgeo.108.3.495. 
Gamble, B.M., 1988, Non-placer mineral occurrences in the Solomon, Bendeleben, and southern part of the Kotzebue quadrangles, western Alaska: U.S. Geological Survey Miscellaneous Field Studies Map MF 1838-B, 13 p., 1 sheet, scale 1:250,000.

Goldfarb, R.J., Hart, C.J.R., Miller, M.L., Miller, L.D., Farmer, G.L., and Groves, D.I., 2000, The Tintina gold belt - a global perspective, in Tucker, T.L., and Smith, M.T., eds., The Tintina gold belt - concepts, exploration, and discoveries: Vancouver, B.C., British Columbia and Yukon Chamber of Mines Special Volume 2, p. 5-34.

Goldfarb, R.J., Baker, T., Dubé, B., Groves, D.I., Hart, C.J.R., and Gosselin, P., 2005, Distribution, character, and genesis of gold deposits in metamorphic terranes: Economic Geology 100th Anniversary Volume, p. 407-450.

Gray, D.J., 2001, Hydrogeochemistry in the Yilgarn Craton; Geochemistry-Exploration, Environment, Analysis, v. 1, p. 253-264.

Hawley, C.C., 2007, Inmachuk exploration project, Seward Peninsula, northwest Alaska: NI 43-101 Technical Report for First Factor Developments, Inc., 57 p., posted June 25, 2007, under Millrock Resources, Inc., on http://www.sedar.com.

Hawley, C.C., and Stevens, D.L., 2009, Inmachuk Prospect, Fairhaven Mining District, Seward Peninsula, Alaska: NI 43101 Technical report, posted October 1, 2009, under Millrock Resources, Inc., on http://www.sedar.com.

Herreid, G.H., 1966, The geology and geochemistry of the Inmachuk River map area, Seward Peninsula, Alaska: Alaska Division of Mines and Minerals Geological Report 23, 27 p., 1 sheet, scale 1:63,360.

Hudson, T., 1999, Alaska resource data file; Bendeleben quadrangle: U.S Geological Survey Open-File Report 99-332, $301 \mathrm{p}$.

Kelley, K.D., and Taylor, C.D., 1997, Environmental geochemistry of shale-hosted Ag-Pb-Zn massive sulfide deposits in northwest Alaska; natural background concentrations of metals from mineralized areas: Applied Geochemistry, v. 12, p. 397-409.

Kelley, K.D., Lang, J., and Eppinger, R., 2010, Exploration geochemistry at the giant Pebble porphyry $\mathrm{Cu}-\mathrm{Au}-\mathrm{Mo}$ deposit, Alaska: Society of Economic Geologists Newsletter, no. 80 (January 2010), p. 1, 18-23.

Leybourne, M.I., and Cameron, E.M., 2010, Groundwater in geochemical exploration: Geochemistry-Exploration, Environment, Analysis, v. 10, p. 99-118, doi:10.1144/14677873/09-222.

Nekrasov, I.Y., 1996, Geochemistry, mineralogy and genesis of gold deposits: CRC Press, 344 p.
Newberry, R.J., Allegro, G.L., Cutler, S.E., Hagen-Levelle, J.H., Adams, D.D., Nicholson, L.C., Weglarz, T.B., Bakke, A.A., Clautice, K.H., Coulter, G.A., Ford, M.J., Myers, G.L., and Szumigala, D.J., 1997, Skarn deposits of Alaska, in Goldfarb, R.J., and Miller, L.D., eds., Mineral deposits of Alaska: Economic Geology Monograph 9, p. 355-395.

Noble, R.R.P, and Gray, D.J., 2010, Hydrogeochemistry for mineral exploration in Western Australia; I, Methods and equipment: Explore, v. 146 p. 2-8, 10-11.

Noble, R.R.P., Gray, D.J., Robertson, I.D.M., and Reid, N., 2010, Hydrogeochemistry for mineral exploration in Western Australia; II, Case studies: Explore, v. 146, p. 12-17.

Piper, A.M., 1944, A graphic procedure in geochemical interpretation of water analyses: Transactions of the American Geophysical Union, v. 25, p. 914-923.

Read, J.J., and Meinert, L.D., 1986, Gold-bearing quartz vein mineralization at the Big Hurrah Mine, Seward Peninsula, Alaska: Economic Geology, v. 81, p. 1760-1774.

Reimann, C., Filzmoser, P., and Garrett, R.G., 2005, Background and threshold; critical comparison of methods of determination: Science of the Total Environment, v. 346, p. 1-16.

Sandvick, P.O., 1956, Report of diamond drilling for radioactive material near Candle, northeast Seward Peninsula: Alaska Territorial Department of Mines Mineral Investigation 44-2, $6 \mathrm{p}$.

Till, A.B., Dumoulin, J.A., Gamble, B.M., Kaufman, D.S., and Carroll, P.I., 1986, Preliminary geologic map and fossil data, Solomon, Bendeleben, and southern Kotzebue quadrangles, Seward Peninsula, Alaska: U.S. Geological Survey Open-File Report 86-276, 60 p., 1 sheet, scale 1:63,360.

Till, A.B., Aleinikoff, J.N., Amato, J.M., and Harris, A.G., 2006, New paleontologic and geochronologic protolith ages for the paleocontinental margin of Arctic Alaska [abs.]: Geological Society of America Abstracts with Programs, v. 38, no. 5, p. 13.

Till, A.B., Dumoulin, J.A., Werdon, M.B., and Bleick, H.A., 2011, Bedrock geologic map of the Seward Peninsula, Alaska, and accompanying conodont data: U.S. Geological Survey Scientific Investigations Map 3131, 75 p., 2 sheets, scale 1:500,000, 1 pamphlet, 75 p., and database, http://pubs.usgs.gov/sim/3131/.

Till, A.B., Dumoulin, J.A., Ayuso, R.A., Aleinikoff, J.N., Amato, J.M., Slack, J.F., and Shanks III, W.C.P., 2014, Reconstruction of an early Paleozoic continental margin based on the nature of protoliths in the Nome Complex, Seward Peninsula, Alaska, in Dumoulin, J.A., and Till, A.B., eds, Reconstruction of a Late Proterozoic to Devonian continental margin sequence, its paleogeographic significance, and contained base metal sulfide deposits: Geological Society of America Special Paper 506, doi:10.1130/2014.2506(01).

Williams, A., 2000, Alaska resource data file, Candle (CA): U.S. Geological Survey Open-File Report 00-025, 109 p. 
Menlo Park Publishing Service Center, California Manuscript approved for publication May 8, 2015

Edited by Peter H. Stauffer and James W. Hendley II Layout and design by Cory Hurd 
